\title{
SPECIFIC TRAINING NEEDS FOR SCHOOL PRINCIPALS IN ANGOLA
}

\author{
M. Abelha ${ }^{1}$, I. Martins ${ }^{2}$, C. Lopes ${ }^{1}$, M.B. Nunes ${ }^{3}$, E.A. Machado ${ }^{1}$ \\ ${ }^{1}$ Univ Portucalense, Portucalense Institute for Human Development - INPP, Oporto \\ (PORTUGAL) \\ ${ }^{2}$ Agrupamento de Escolas de Estarreja (PORTUGAL) \\ ${ }^{3}$ Univ Portucalense, Portucalense Institute for Legal Research - IJP, Oporto (PORTUGAL)
}

\begin{abstract}
The school principal is responsible for the achievement of the school's educational goals, the proper performance of all the school members and the fulfillment of the quality patterns defined by the learning system and the national or local legislation (Lück, 2009) [1].

Within the Angolan educational system, the nomination of school principals appears to be more a matter of politics than particular academic and professional competencies of those who are appointed to the job. It is therefore urgent to rethink the formal and non-formal training of school principals, to avoid a situation where the school management is based more on good sense and reactive responses than in a knowledge-based action.

In this context, the present case study, centered in the High Schools of the Benguela Municipality (Angola), aims to define a set of competencies that should be required for the job and, hence, the specific training needs for the exercise of the school principal's functions.

In order to respond to this research question three goals were defined: i) to characterize the academic and professional profile of the school principals of the 1st Cycle of Benguela's High School Principals; ii) to diagnose the training needs of the school principals of the 1st Cycle of Benguela's High School Principals; and iii) to produce knowledge about the specific training needs for the exercise of the school principal's job in High Schools of the Benguela Municipality.

The empirical study was developed during the academic year of 2014. A mixed methodology was used, and data collection was based on institutional documentation, participatory observation and a questionnaire created by the authors of the present study. The sample coincides with the population and consists of all the 25 school principals of the Benguela Municipality High Schools. Preliminary data analysis that will be presented in this paper is based on descriptive statistic technics applied to the results of the inquiry.

In the face of the multiplicity of competences and intrinsic dynamics of the situations that may occur in school context, results show that there is an effective need of investment in specialized training for the exercise of the job of school principal; in fact, besides specific programs centered on specific themes, theoretical and practical post-graduate training is demanded, making it possible for future and existing school principals to analyze and reflect on the job, characterized by complex situations that can't be solved or predicted without qualified knowledge, no matter how many years someone has already experienced on the exercise of the functions.
\end{abstract}

Keywords: school principal, training needs, school management.

\section{INTRODUCTION}

The present paper focuses on the specific training needs for the exercise of the school principal's functions in the first cycle of Benguela High Schools (Angola), in the context of the challenges presented by the teaching and learning processes. The assumption that the role of the school principal is not merely bureaucratic, but also pedagogical, and the acknowledgment of the fact that, in Angola, school principals are nominated under political proposal, therefore disregarding any qualified training, makes this a specially relevant subject.

Both professional development and teacher's training are inter-related: according to Marcelo (2009)[2], professional development is an individual or collective process realized at school and which goal is to develop the expertise and professional competencies of teachers, with resort to different formal and informal experiences. As such, professional development is directly influenced by the personal and 
professional life of each individual, as well as by the school contexts and policies in which professional activities are exercised (Day, 2001)[3].

The concept of 'development' is related to a continuous process of qualitative and quantitative changes which, occurring over time, are the result of different interactions between the subjects and their contexts. The various educational actors assume an active role in the formulation of purposes within the professional performance of teachers; on the other hand, the production of knowledge in this field is not exclusive of academic schools or research centers. The wisdom of practice, knowledge-in-action (Schön, 1983)[4] and the concepts that support that wisdom is a repertoir that may be reflectively optimized, leading to change in educational practices. Nevertheless, "professional reflection doesn't guarantee on its own the quality of teaching practices, for it may serve different objectives, including justification and reinforcement of anti-democratic and discriminatory practices" (Vieira, 2010, p. 16)[5]. Therefore, it arises the necessity of building correlations between the reflective process and political and ethical purposes that underpin the educational act.

Besides the meaning that is attributed to the different interactions, it is important to highlight the matching of the subjects' conceptions about teaching and the concepts of the organization. In a study about learning opportunities in community contexts, Little, Horn \& Bartlett (2002)[6] state that the degree of compatibility between individual conceptions and community conceptions tends to be proportional to the level of commitment of the subjects.

In this sense, the potential of that interaction regarding the professional growth and a collegiate culture points out to the emergence of an open and critical relationship with the faculty work, showing an increasing professional autonomy and valuing knowledge and established relational networks in which the subjects evolve. From questioning and researching in and on practice, real problems, doubts, tensions and critical incidents emerge, potentially promoting professional development. Fullan \& Hargreaves state that "the most important will be the type of involvement and the particular way in which teachers work together with the community" (2001, p. 37)[7]. On its turn, the articulation between the faculty work context with the training one emphasizes the centrality of professional knowledge and values (Roldão, 2002)[8], harnessing the training dimension of work situations (Machado \& Formosinho, 2009)[9].

As with learning, training is a road that assumes formal (attendance to credited courses, for instance) and informal (self-training, for example) ways. However, it will always be a personal and individual process, which sense "depends on the personal and professional lives and school policies and contexts where they develop their teaching activity." (Day, 2001, p. 15)[3].

We can now understand that not all activities are, by themselves, developmental, even if integrated into a formal training process. The educational nature of a given activity needs to be validated and legitimated by the trainee as a "useful and compensating experience". To this process also concurs what the author calls "the forces in presence" (Alarcão, 2006, p. 137)[10] in the context of the immediate development of the teacher. These effects come from the relationship between the immediate context with other settings, even wider, such as the educational policies, which assume themselves as facilitators or conditioners of the training activity and professional development of the teacher.

That's how professional development implies the consideration of the vocational and personal dimensions of teachers, in a continuous process (and not as an arriving point), consistent with the learning and training conceptions, which remit to the individual and his contexts, and where nonlinearity is an intrinsic characteristic. Concepts don't present unique and static meanings, and for that greater goals underpin professional development, such as personal and professional well-being and the growth in quality of the teaching and learning processes.

In short, teachers' professional development is based on a 'Conception of teachers' autonomy as a display of the collective ability to conceive and execute, in an original and contextualized way the work that is entrusted to them, so that they can evaluate and redefine it whenever proven necessary" (Esteves, 2006, p. 246)[11]. In this line of thought, faculty professional development has several implications, namely in what refers to the quality of the teaching and learning processes (Day, 2001)[3], involving, besides the personal and professional dimensions, the organizational dimension (Nóvoa, 2002)[12]. This fact brings sociopolitical consequences that may leverage the development of the society, which is intended to be democratic and equitable.

Indeed, the role of the school principal is located at the interface of society's quests, nature and goals of education and, among others, the professional developing processes of the teacher. Ergo, the 
school principal is "the professional responsible for the leadership and organization of all those who work at the school, in order to guide them in the development of an educational environment capable of promoting the learning and training of the pupils at the highest level possible, making it possible for them to face the defies that are presented to them" (Lück, 2009, p. 17)[1].

Through a participatory leadership, the school principal is therefore responsible for promoting changes in the relations, dynamics of teachers' work, pedagogical practices that ensure the quality of the education that is offered, aiming to attain established goals, building the school's identity and respecting the character of the people that are part of it. As such, "the school principal is the leader, the mentor, the coordinator and primary guide of the school's life and all of its educational work" (Lück, 2009 , p. 23)[1]. Their responsibility may be shared with the other members of the school community in the sense of promoting a wider compromise of all those that are involved in the educational activities. Nevertheless, it should not be dissolved, for it's their job to ensure harmony within the school organization.

In this line of thought, Libâneo (2004)[13] considers the following attributions of a school principal: i) to supervise pedagogical and administrative activities; ii) to promote integration between the school and the community; iii) to know the legislation; iv) to find means that enhance the members of the team, among others. However, the exercise of these responsibilities requires a continuous training, meaning that the director is always in pursuit of improvement and maturation, "thus creating a background of enriched experiences which, shared with the peers favors professional development" (Silva, 2009, p. 73)[14]. That's why development and permanent knowledge actualization must be an integrant part of the daily life of a school principal, as a process of in-service capacitation, to re-analyze and revalidate the competencies in the exercise of the job and its inherent functions.

Given this reality, it is urgent to rethink the training of school principals, to avoid that they face their responsibilities within the school context reacting based only upon good sense and results of trial-anderror. Curricular and pedagogical dimension, management of educational projects, human and financial resources and facilities, performance assessment, interpersonal relations, promotion of learning success, valuing the participation of all the educational actors, conflict management, partnerships enrolment, among others, are examples of situations that directors will face on a daily basis and to which they will be called to respond, regardless their basic training and experience.

Being a school principle implies the mobilization of multiple specific competencies from several fields, representing a constant challenge. Due to this multiple skills and the inner dynamism of the situations that occur in the school context, we consider necessary and fundamental to invest in the training of school principals ensuring that, besides special programs focused on specific themes, post-graduate training processes, both theoretical and practical, should be offered to them, so that they can analyze and reflect on the situations that characterize the specificities of the job.

The need to invest in the training of school principals is emphasized in the Angolan educational context, for the nomination is made by the Province Governor, under the proposal of the Provincial Director of Education and for a period of three years, renewable for equal terms (Presidential Decree n. ${ }^{0} 16 / 11$, of 11 January). In conformity with the legislation, recruitment for the exercise of the job of director of the general teaching establishments must mandatorily fall over an effective teacher, working full-time, that possess the higher category and, at least, five years of good and effective service at the establishment. Holders of directive jobs take office before the Provincial Governor. Exoneration of the job is, equally, a competence of the Provincial Governor.

After nomination, the director takes office and presents a proposal for a board, whose appointment and charge taking are a competence of the Provincial Director of Education. At the beginning of each school, year boards have the possibility of proposing adjustments to the supporting teams, if they find it necessary. It is important to notice that the owners of directive boards of the subsystem of teachers training have a college degree and are obliged to exercise the job in a regime of exclusivity.

\section{METHODOLOGY}

The research problem of the present study focuses on the analysis and comprehension of the importance of the need for specific training for the exercise of the job of school principal in 1st Cycle High Schools of the Municipality of Benguela and is represented by the following question: What are the specific training needs of school principals of the 1st Cycle High Schools of the Municipality of Benguela? 
In order to respond to the research question, the following goals were designed: i) to characterize the academic and professional training of the school principals of 1st Cycle High Schools of the Municipality of Benguela; ii) to diagnose training needs of the school principals of 1st Cycle High Schools of the Municipality of Benguela; iii) to acquire knowledge about specific training requirements for school principals in the Angolan context.

For this research, a mixed methodology was adopted: quantitative methods were used to gather data through a survey applied to school principals of the 1st Cycle High Schools, and qualitative methods were used through non-participatory observation in a natural context and documental analysis. Nevertheless, our analysis will be focused on the results obtained through the application of the survey.

The empirical study occurred during the school year of 2014; all the schools of the 1st Cycle High Schools of the Municipality of Benguela were selected, and consequently, all the school principals $(\mathrm{N}=25)$ were inquired. The primary goal of the survey was to understand, through their voices, the opinions of school principals regarding their training needs for the exercise of the job.

The survey was structured in two parts: i) personal and professional characterization, and ii) exercise of the position of school principal. The first part was composed of a set of seven questions aiming to obtain data to characterize personal and professionally the respondents. The second part was composed of a set of eighteen situations about which respondents were asked to comment on their training needs; a Likert type scale was used, with three answering options: 1=No difficulty; 2=Some difficulty; $3=$ Much difficulty. The situations presented in the survey were organized in eight dimensions of analysis, as illustrated in Table 1.

Table 1. Relationship between dimensions of analysis and represented situations.

\begin{tabular}{l|l}
\hline \hline Dimension of analysis & \multicolumn{1}{c}{ Represented situations } \\
\hline $\begin{array}{l}\text { Curricular and } \\
\text { pedagogical management }\end{array}$ & $\begin{array}{l}\text { Development and organization of pedagogical innovation experiments. } \\
\text { Educational support for pupils with special educational needs. }\end{array}$ \\
\hline $\begin{array}{l}\text { Educational projects } \\
\text { management }\end{array}$ & Elaboration and development of educational projects. \\
\hline Financial Management & Elaboration of school budgets. \\
\hline $\begin{array}{l}\text { Odministrative } \\
\text { management }\end{array}$ & $\begin{array}{l}\text { Elaboration of internal documents of the school (internal regulation, activities plan, } \\
\text { training plan...). } \\
\text { Setting up of classes and schedule elaboration. }\end{array}$ \\
\hline $\begin{array}{l}\text { Human resources } \\
\text { management }\end{array}$ & $\begin{array}{l}\text { Distribution of teaching and non-teaching service. } \\
\text { Selection and recruitment of teaching staff. } \\
\text { Elaboration of the training and updating plan for teaching and non-teaching staff. } \\
\text { Hiring of non-teaching staff. }\end{array}$ \\
\hline \hline $\begin{array}{l}\text { Facilities management } \\
\text { management }\end{array}$ & $\begin{array}{l}\text { Facilities, spaces and equipment management. } \\
\text { Use of information and communication technologies. }\end{array}$ \\
\hline $\begin{array}{l}\text { Interpersonal relations } \\
\text { management }\end{array}$ & $\begin{array}{l}\text { Performance evaluation of the teaching staff. } \\
\text { Performance evaluation of the non-teaching staff. }\end{array}$ \\
$\begin{array}{l}\text { Leadership exercise with teaching and non-teaching staff. } \\
\text { 1onflicts management and prevention of indiscipline and violence situations. } \\
\text { Information communication and diffusion. } \\
\text { Enrolment of parents and guardians in the school life. }\end{array}$ \\
\hline
\end{tabular}

Once closed the data gathering, its analysis and interpretation were realized recurring to technics of descriptive statistics analysis. 


\section{RESULTS}

The presentation and discussion of results are organized having for reference the objectives of the study and part of the theoretical references that supported the research.

\subsection{Caracterization of the academic and professional training of the school principals}

Bachelor (in Portuguese, "Licenciatura") is the most common degree: 14 of the 25 principals are bachelors, while six claim to have a post-graduation and five a master degree, as shown in Table 2:

Table 2. Academic degrees.

\begin{tabular}{l|c|c}
\hline \hline & Frequency & Percentage \\
\hline Bachelor degree & 14 & $56 \%$ \\
\hline Post-graduation & 6 & $24 \%$ \\
\hline Master degree & 5 & $20 \%$ \\
\hline \hline
\end{tabular}

The scientific field of the principals' degrees is diverse: Pedagogy is the course with more responses (4), followed by Psychology, Geography, and History (3 each). On the other hand, the respondents that affirmed to have a master degree did it mainly in educational areas: 2 in Administration and Management of Education, 1 in Educational Centers Management and 2 in School Management and Supervision. The post-graduation mentioned by 6 of the principals were diverse and realized mainly in the course of continuous professional training.

During the exercise of their jobs, school administrators face multiple heterogeneous situations, at the administration and management level, as well as the degree of teaching practices, which need different responses, thus being natural that training gains progressive relevance for the respondents.

Learning has a practical and dynamic character that has reflections on the personal and professional life of any individual in the context of an organization (Day, 2001)[5]. In this sense, training appears to be a fundamental tool for the development of new and existing competencies, implying values, knowledge and abilities that can be anticipated, accept rapid changes, solve questions related to complex, distinct and unequal contexts, facilitate the analysis and sharing of decision options, dealing with participation processes and adapting to new institutional circumstances and demands, e.g. enhancing the training dimension of the work environment (Machado \& Formosinho, 2009)[9].

It is important to stress out that the relevance of the training is highly emphasized when the subjects are school principals, people leading scholarly organizations who have an additional responsibility in the education and learning of future citizens.

\subsection{Training needs of school principals}

Diagnosis of training needs of school principals of the 1st Cycle High Schools of the Municipality of Benguela had by reference a set of eighteen situations presented in the survey. These situations were grouped in eight analysis dimensions, which results will be described in the next section.

\subsubsection{Curricular and pedagogical management}

In this dimension, it was evident that the respondents assumed to have training needs at the level of "Educational support for pupils with special educational needs" $(100 \%)$ and "Development and organization of pedagogical innovation experiences" $(88,0 \%)$. These results show that their primary training is not yet suitable to a good level of response to this kind of situations and, on the other hand, that the teaching staff may not be sufficiently motivated to deal with the referred situations. As a matter of fact, if we analyze the characteristics listed by article 11 of the Decree number 3/08 of March 4th, which present the desired profile of the candidate to the profession of teacher in the Secondary Education in Angola, the development, and organization of pedagogical innovation experiences is omitted and, regarding the attention due to students with special educational needs, the only demand is "to identify the young person in need of special assistance and care". It is therefore clear why school principals that answered the survey state training requirements at the level of pedagogical and curricular management regarding these particular situations. 


\subsubsection{Management of educational projects}

In this dimension, we verified that $92,0 \%$ of the principals assumed the need of training regarding the "Elaboration and development of educational projects," though the designation of "educational projects" may have been subject to different interpretations by the respondents. Nevertheless, the high level of responses leads to the inference that the principals' action focuses strictly in what is legally prescribed, regardless of more comprehensive aspects which, according to Lück (2009)[1], deal with the construction of their own educational program: this program should explicitly express the actions to be developed at the level of educational policies, challenges and guidance and training of the students. Libâneo (2004)[13] equally refers that the main attributions of a school principal must contemplate: i) administrative and pedagogical activities supervision; ii) promotion of the integration between the school and the community; iii) knowledge of legislation; iv) search for means to potentiate the team members, among others.

\subsubsection{Financial management}

Only $16,0 \%$ of the respondents considered they didn't need any training regarding the situation "Elaboration of school budgets". It is important to stress that these principals held the office in 1st Cycle High Schools and, therefore, they didn't have financial capacity. Nevertheless, it is relevant that budget planning is considered a competence of school principals, in order to improve their management of financial resources assigned to the schools; on the other hand, this skill is needed to develop partnerships with other organizations, with the purpose of raising funds to the acquisition of pedagogical resources, needed to the improvement of teaching practices and academic success.

\subsubsection{Administrative and organizational management}

In this dimension, $56,0 \%$ of the respondents considered they didn't feel the need of training regarding the situation "Setting up of classes and Schedule elaboration", showing that there is some degree of domain of the tasks related to the organizational nature of the school and its daily dynamics. On the other hand, $60,0 \%$ of the principals stated the need of training regarding the "Elaboration of internal documents of the school (internal regulation, activities plan, training plan...)". These results may be a sign that the principals that were the subject of this study are not yet promoting an environment suitable to the enrollment of all the school community, distributing tasks and assuring that different teams feel responsible for their achievement. Implementing such an environment tends to enroll collaborators in search of solutions, common grounds and projects involving all the school community, thus contributing to a harmonious development of the school.

\subsubsection{Human resources management}

In this dimension of analysis, $72,0 \%$ of the respondents stated not to feel the need of training regarding the "Distribution of teaching and non-teaching service", thus revealing to domain abilities in the management of this type of human resources. In contrast, at the levels of "Selection and recruitment of teaching staff" and "Hiring of non-teaching staff", $72,0 \%$ stated the need for more training. These results cause some perplexity, for, in the context of 1st Cycle High Schools of the Municipality of Benguela, selection and recruitment of teaching and non-teaching staff are areas whose responsibility is not assigned to school principals. We wonder if these results show a desire of a future assumption of a more active role in the recruitment of teaching and non-teaching staff by the school principals.

Concerning the situation "Elaboration of the training and updating plan for teaching and non-teaching staff", $88,0 \%$ of the respondents declared they needed more training, thus showing professional lacks at this level. However, this matter is a means to achieve teaching quality and a necessity to attend the demands of nowadays world and its relevance is of particular significance within the competences of any principal who wishes to capacitate and promote the success of the school he or she leads. In the assumption that "the school principal is the leader, the mentor, the coordinator and the primary guide of the school life and all of its educational work" (Lück, 2009, p. 23)[1], it is a competence of the principal to ensure the harmony of the organization, looking after it as a whole and assuming as the focus of his or her actions, at all time, the learning and training of all the educational actors.

\subsubsection{Facilities management}

Regarding the situations "Facilities, spaces and equipment management" and "Use of information and communication technologies", $88,0 \%$ of the respondents stated the need for training. It is, however, 
curious to notice that the results obtained regarding the first situation are contradictory with the $72,0 \%$ that, in a precious moment, declared not to feel the need of training regarding the "Distribution of teaching and non-teaching service", and the $56,0 \%$ that stated the same in relation to the "Setting up of classes and Schedule elaboration". This contradiction is because "Facilities, spaces, and equipment management" is directly related to the distribution of teaching and non-teaching service and, on the other hand, with the setting up of classes and schedule elaboration.

Regarding the "Use of information and communication technologies", it is important to recall that only one of the 25 schools that were object of this study had a computers room duly equipped. However, in this situation, the need of training stated by the respondents is understandable, for they may be expecting that the Ministry of Education will equip schools in the near future.

\subsubsection{Performance evaluation management}

In this dimension, $56,0 \%$ of the principals answered that "Performance evaluation of the teaching staff" was not a matter of concern regarding further or specialized training; however, $32,0 \%$ of them felt the need of "some" training. Regarding the situation "Performance evaluation of the non-teaching staff" there was a less noticeable divergence: $48,0 \%$ chose the option "None" and $44,0 \%$ stated the need for "Some" need of training.

Assessment of teaching and non-teaching staff is a responsibility of the school principal. In the assumption that there is a protocol that defines clearly the goals to achieve, and that is acknowledged by both parts, it can be inferred that assessment may be a positive way of valuing teaching and nonteaching staff that look for quality in their functions, promoting academic success and taking care of the harmony of the school; on the other hand, it allows the detection of aspects that need to be upgraded, in order to optimize the abilities of all individuals and, if necessary, re-adjust their functions.

\subsubsection{Interpersonal relations management}

In this dimension, $60,0 \%$ of the respondents referred the need of training in "Leadership exercise with teaching and non-teaching staff". This result may reveal the existence of hidden leaderships in some of the schools and also a self-conscience regarding the necessity of a more proactive and democratic role exercise of the principals' functions, involving and listening to the maximum of people possible before decisions are taken.

"Conflicts management and prevention of indiscipline and violence situations" is marked by $84,0 \%$ of the principals as a situation that they feel they lack training. Conflicts and indiscipline situations are aspects that arise from the gaps that characterize contemporary societies and that are reflected in the school context. It is therefore understandable the need for training evidenced by the school principals, for in many cases mediation of conflicts is up to them.

The situation "Information communication and diffusion" was marked by $56,0 \%$ of the respondents as one where they didn't feel the lack of training, thus revealing that these principals are still able to communicate with the different elements of the school community and, most probably, with other partners.

As for the situation "Enrolment of parents and guardians in the school life", it was pointed out by $72,0 \%$ of the principals as one that needed more training - as a matter of fact, it is a responsibility of the principals to promote dialogue and create participatory environments, involving different elements of the school community, especially parents and guardians. These are direct players in the pupils' education, and therefore must have a close contact with the school to make it possible to act together, fast and efficiently, thus being a guarantee of the academic success of their children.

\subsection{Development of Knowledge regarding specific training needs for school principals in Angola}

The primary training needs pointed out by the 25 principals of 1st Cycle High Schools of the municipality of Benguela stand at the following levels: Curricular and pedagogical management, Educational projects management, Financial management and Interpersonal management. It should be stressed that, regarding the dimension Human resources management, $88,0 \%$ of the respondents pointed out the need for training in the situation "Elaboration of the training and updating plan for teaching and non-teaching staff"; in regard to the same dimension, $72,0 \%$ of the principals state a necessity for training in the situations "Selection and recruitment of teaching staff" and "Hiring of non- 
teaching staff" - however, in the case of the schools that were subject to this study, principals are not responsible for the selection and hiring of staff.

The findings of this research confirm that the exercise of the functions of school principal require a continuous and on-going education, meaning a headperson in permanent search, improvement, and maturation, "thus creating a various amount of enriched experiences which, shared with the peers, favor professional development" (Silva, 2009, p. 73)[14]. Also, this lifelong learning must be, on one side, suited to the specific needs of each principal and, on the other hand, consider the real school context where the job is exercised.

\section{CONCLUSIONS}

In the context of nowadays society, the nature of education and the goals of the school assume a more dynamic, complex and broader dimension, reflecting on the professional performance of the different educational actors, especially if we are talking about school principals. As leaders, they "need to pay attention to change and be able to predict it and react when it shows, always regarding the interests of the organization; they have to affirm themselves as real actors of change and reconstruction of the organizational culture of the school they lead" (Barreto, 2009, p. 86)[16].

Findings resulted in the conclusion that most of the 25 principals that were subject of this study had a vast experience on the job, for 15 of them exercised it from between 19 to 30 years and five of them for more than 30 years. If we match this evidence with the text of the article 42 of the Presidential Decree number 16/11, of 11 January, which states that school principals are nominated by the Province Governor, under proposal of the Provincial Director of Education and for a period of three years, renewable for equal terms, we can state that 20 of the 25 principals have been obtaining the renewal of their service commission by the Province Governor, after approval of the Education Provincial Director. This reality leads to two questions:

1 In the exercise of a leadership position, the length of service influences the quality of the performance, bringing a supplement of professional competencies and abilities that have an impact on the success of the relationships between the educational community and within the teaching and learning processes?

2 Could a large length of service in the exercise of the same position lead to situations of implementation of routines and crystallization of practices?

These two questions are of such importance that it should be stressed that an answer to them could be pursued through a future study to be developed with the very same subjects and others of the municipality of Benguela.

Considering the research problem that guided this study, we observe that most principals that answered the survey assumed that they had training needs mainly in what regards the following dimensions: Curricular and pedagogical management, Educational projects management, Financial management and Interpersonal management. It should be stressed out that $88,0 \%$ of the headmasters pointed out training needs in "Elaboration of the training and updating plan for teaching and non-teaching staff" (dimension human resources management). Findings show clear evidence that the respondent, all broadly experienced school principals, lack specific training in several of the dimensions that the job implies, meaning that the long years of experience are not enough to guarantee the ability to find solutions to the challenges of contemporary society.

In the face of these results, we present some suggestions that we expect will be considered by the participants of the study: i) attendance of post-graduation courses in the field of School administration and management, Curricular and pedagogical management, Educational projects construction and Conflicts management (other areas of expertise could also be considered); ii) annual identification of specific training needs for the faculty staff, including non-teaching staff, in order to create an annual plan of training; iii) the establishment of partnerships with academic institutions, ensuring the efficient realization of the training courses envisaged by the annual training schemes; iv) the sharing, discussion, and analysis of their management practices with other school principals; $v$ ) the individual reflection and, later, with other school principals, on the impact of decisions on the teaching work dynamics and the students learning process; vi) the realization of school meetings around a particular theme, where pupils, parents, and guardians are called to intervene and participate in the finding of solutions. 


\section{REFERENCES}

[1] H. Lück, Dimensões da gestão escolar e suas competências, Curitiba: Editora Positivo, 2009.

[2] C. Marcelo, "Desenvolvimento Profissional Docente: passado e future," Sísifo - Revista de Ciências da Educação, no. 8, pp. 7-22, 2009.

[3] C. Day, Desenvolvimento Profissional de Professores: Os desafios da aprendizagem permanente, Porto: Porto Editora, 2001.

[4] D. Schön, The Reflective Practitioner: How professionals think in action, New York: Basic Books, 1983.

[5] M.F. Vieira, "Formação reflexiva de professores e pedagogia para a autonomia: para a constituição de um quadro ético e conceptual da supervisão" In No Caleidoscópio da Supervisão: Imagens da formação e da pedagogia (M.F. Vieira, M. Moreira, I. Barbosa, M. Paiva \& I. Fernandes), pp.15-45, Mangualde: Edições Pedago, 2010.

[6] J. Little, I. Horn \& L. Bartlett, L. "Identidade, comunidade e empenho: Tópicos emergentes na investigação sobre o ensino secundário," Revista de Educação: Identidade e Desenvolvimento Profissional dos Professores, no. 2, pp. 9-20, 2002.

[7] M. Fullan \& A. Hargreaves, Por que vale a pena lutar? O trabalho de equipa na escola, Porto: Porto Editora, 2001.

[8] M.C. Roldão, "A centralidade do saber e agir profissionais versus a discussão de modelos," Revista de Educação, Formação de Professores, Testemunhos e Perspectivas, no. 1, pp. 157158, 2002.

[9] J. Machado \& J. Formosinho, "Professores, escola e formação. Políticas e práticas de formação continua," In Formação de Professores. Aprendizagem profissional e acção docente (J. Formosinho, Coord.), pp. 287-302, Porto: Porto Editora, 2009.

[10] I. Alarcão, "Continuar a formar-se, renovar e inovar," In Isabel Alarcão: Percursos e Pensamento (I. Sá-Chaves et al., Orgs.), pp. 129-154, Aveiro: Universidade de Aveiro, 2006.

[11] M. Esteves, "Formar professores como profissionais autónomos," In Formação de Professores de Línguas Estrangeiras: Reflexões, estudos e experiências, (R. Bizarro \& F. Braga, Orgs.), pp. 243-250, Porto: Porto Editora, 2006.

[12] A. Nóvoa, Formação de Professores e o Trabalho Pedagógico, Lisboa: Educa, 2002.

[13] J.C. Libâneo, Organização e gestão da escola: Teoria e prática, Goiânia: Alternativa, 2004.

[14] E. Silva, "A importância do gestor educacional na instituição escolar," Revista Conteúdo, vol. 1, no. 2, pp. 67-83, 2009.

[15] A. Barreto, "Liderança Transformacional na Escola. Um estudo de caso de o presidente de um agrupamento", Aveiro: Universidade de Aveiro, 2009. 